\title{
EFFECT OF COMPACTING IRRIGATION FURROWS ON THE PRODUCTIVITY OF WHEAT SOWN ON BEDS
}

\author{
ATTAFY, T. M. 1; W. B. FAKHRANY'; \\ S. A. SHALABEY ${ }^{1}$ and E. M. A. GEBREL ${ }^{2}$
}

${ }^{1}$ Agric. Eng. Res. Inst., ARC, Giza, Egypt.

2 Field crop Res. Inst., ARC, Giza, Egypt.

\begin{abstract}
$\mathrm{F}$ ield study was conducted at the Gemmeiza Research Station, Gharbeiah Governorate, middle of the Nile Delta, Egypt, having a clay textured soil during two winter seasons of $2015 / 16$ and 2016/17. The aim of the current research was to estimate effect of sowing pattern, furrow compaction and water flow rate on improving surface irrigation performance and wheat productivity. Surface irrigation system was studied at two different sowing patterns flat $(F)$ and bed. Bed sowing was applied at three compaction levels; no compaction (NC), compaction one pass $\left(\mathrm{C}_{1}\right)$ and compaction two passes $\left(\mathrm{C}_{2}\right)$. Three flow rates values of $0.4 \mathrm{~L} \mathrm{~s}$ ${ }^{1}\left(Q_{1}\right), 0.6 \mathrm{~L} \mathrm{~s}^{-1}\left(\mathrm{Q}_{2}\right)$ and $0.8 \mathrm{~L} \mathrm{~s}^{-1}\left(\mathrm{Q}_{3}\right)$ to closed long furrows of 60 $\mathrm{m}$ length without dikes were investigated under two sowing methods. Advance time, total applied water, stored water, application efficiency, water distribution efficiency, yield and yield components and water productivity were measured and discussed. Main results cleared out that:

1- The applied water during bed sowing treatments advanced faster compared with flat sowing.

2- Bed sowing and furrow compaction two passes "C2" saved irrigation water by about $33.8 \%$ per feddan in average comparing with flat sowing under three different flow rates.

3- Using bed sowing and furrow compaction two passes "C2" enhanced application efficiency by about $14.7 \%$ and water distribution efficiency by about $11.9 \%$ in average comparing with flat sowing.

4- Wheat grain yield and water productivity increased by about $11.7 \%$ and $68.8 \%$ respectively in average under bed sowing and furrow compaction two passes " $\mathrm{C} 2$ " comparing with flat sowing.

The furrow compaction technique under bed sowing is convincingly better compared with flat sowing.
\end{abstract}

\section{INTRODUCTION}

Wheat is the most important cereal crop in Egypt, where it has strategic value in the Egyptian diet commodities. In Egypt especially in Delta region, flooding is considered a traditional surface irrigation method for wheat crop. This mean excess applied water, low irrigation efficiency, low grain yield and low water productivity. One opportunity to enhance surface irrigation and minimize its disadvantages is application raised beds, where seeds drilled on bed surface, irrigation is applied through the furrows between beds and water reaches to the wheat rows by lateral infiltration. 
Fahong et al. (2004) resulted that, changing from flood irrigation to raised bed planting method with furrow irrigation saved applied irrigation water by about $17 \%$ and improved water use efficiency by about $25.5 \%$. Hossain et al. (2009) showed that, sowing wheat on beds had significantly higher grain yield and yield component comparing with conventional method of sowing. Where, sowing on beds allowed plants to uptake more moisture and nutrients. Mushtaq et al. (2012) resulted that, raised bed planting method for wheat saved by about $22.47 \%$ of irrigation water comparing with flat sowing method. El-Sayed (2015) the raised beds sowing method should be applied in the condition of irrigation water deficit, where saving irrigation water and increasing wheat grain yield and water use efficiency was happened. Sorour et al. (2016) increasing irrigation water under flat planting method compared with raised beds method may be attributed to increase irrigation area, time of irrigation, amount of water percolation, seepage and evaporation.

Furrow compaction can be used to increase irrigation efficiency of bed sowing method, where proper compaction moves soil particles close together and limits airwater movement through soil column consequently decreases porosity, water holding capacity and infiltration of the soil, all this contribute to improve water distribution and decreased potential for deep percolation at the head end of the field. Yonts and Eisenhauer (2007) indicated that, furrow firming improved water advance comparing with conventional furrow, where in the firmed furrow water advanced more than twice the distance than water in the conventional furrow. They stated that, any process allowing water to advance in a furrow and reach the end of the field faster will help improve water distribution and obtain more uniform irrigation. Beutler et al. (2008) resulted that, small compaction can increase soybean yield, while no compaction and excessive compaction can cause a smaller plant growth consequently reduced soybean yield. Kirnak et al. (2013) studied effect of soil compaction (no compaction, low compaction and high compaction) in clay soil on irrigation and soybean yield parameters. Their results indicated that, the highest irrigation water was observed in no compaction treatment while the lowest was observed in high compaction treatment. Soybean yield was increased from no compaction to low compaction treatments but decreased from low compaction to high compaction treatments; yield losses at high compaction treatments may reach up to 45\%. Montaserei et al. (2016) studied the effect of furrow compaction on some water relation and sugar beet yield; they concluded that, furrow firming by roller increased water advance rate in furrow and improved irrigation efficiency and water productivity but had no significant effect on quality and quantity of sugar beet yield. 
Ali (2011) in clay soil, the distance between furrows ranged from 75 to $150 \mathrm{~cm}$ and flow rate up to $0.5 \mathrm{~L} \mathrm{~s}^{-1}$ is suitable for furrows that are not too long; in general, it is not advisable to use flow rate larger than $3 \mathrm{~L} \mathrm{~s}^{-1}$. Akbar et al. (2017) application of wide beds under a low infiltration soil can produce negative effects on crops in the bed middle due to poor lateral infiltration; therefore, convenient management of bed furrow sizes according to soil and field conditions has the potential to save irrigation water and increase crop yield, and thus increase water productivity.

The main objective of this work is to estimate how far sowing pattern, soil compaction and flow rate could be followed to improve surface irrigation performance and wheat grain yield.

\section{MATERIALS AND METHODS}

\section{Site description:}

This study was carried out at the Gemmeiza Research Station, Gharbeiah Governorate, middle of the Nile Delta, Egypt, during two successive winter seasons of $2015 / 16$ and $2016 / 17$. The soil at the experimental site was characterized as clay soil, cultivated with field crops, some physical properties and some soil hydrodynamic constants of the experimental soil were determined according to Black et al. (1965) and are presented in Table 1.

Table 1. Soil mechanical analysis and some physical properties of experimental field

\begin{tabular}{|c|c|c|c|c|c|c|c|}
\hline \multirow[b]{2}{*}{$\begin{array}{l}\text { Depth } \\
(\mathrm{cm})\end{array}$} & \multicolumn{3}{|c|}{ Particle size distribution } & \multirow{2}{*}{$\begin{array}{l}\text { Bulk density } \\
\quad\left(\mathrm{g} \mathrm{cm}^{-3}\right)\end{array}$} & \multirow{2}{*}{$\begin{array}{c}\text { Field } \\
\text { capacity } \\
(\mathrm{mm})\end{array}$} & \multirow[b]{2}{*}{$\begin{array}{l}\text { Wilting point } \\
\qquad(\mathrm{mm})\end{array}$} & \multirow{2}{*}{$\begin{array}{c}\text { Available } \\
\text { soil water } \\
(\mathrm{mm})\end{array}$} \\
\hline & $\begin{array}{l}\text { Clay } \\
(\%)\end{array}$ & $\begin{array}{l}\text { Sand } \\
(\%)\end{array}$ & $\begin{array}{l}\text { Silt, } \\
(\%)\end{array}$ & & & & \\
\hline $0-15$ & 49.07 & 16.73 & 34.20 & 1.15 & 45.53 & 21.31 & 24.22 \\
\hline $15-30$ & 52.27 & 12.31 & 35.42 & 1.25 & 44.58 & 20.97 & 23.61 \\
\hline $30-45$ & 53.92 & 9.70 & 36.38 & 1.28 & 42.99 & 18.53 & 24.46 \\
\hline $45-60$ & 51.6 & 11.56 & 36.84 & 1.32 & 40.86 & 21.29 & 19.57 \\
\hline
\end{tabular}

The experimental field was prepared using the traditional preparing method (Chiseling twice + traditional leveling). Wheat Gemmeiza 12 variety was sowed on flat soil on $1^{\text {st }}$ and $3^{\text {rd }}$ November, 2015 and 2016 for all treatments by a seed drill (Tye seed drill) at distance $15 \mathrm{~cm}$ between rows, field length was $60 \mathrm{~m}$ with closed end. For bed treatments, beds were raised at a height $15 \mathrm{~cm}$ and distance $120 \mathrm{~cm}$ between beds (net beds width were $90 \mathrm{~cm}$ ) as shown in Fig. 1. All cultural practices in the experimental field were carried out according to agricultural recommendations for wheat. Wheat was irrigated 5 irrigations in season which scheduled as shown in Table 2. 


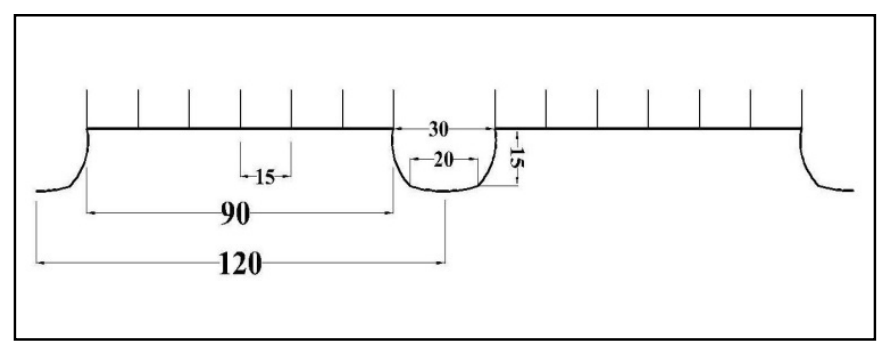

Fig. 1. Schematic diagram showing bed dimensions

Table 2. Irrigation scheduling for wheat crop.

\begin{tabular}{|l|l|l|}
\hline \multicolumn{1}{|c|}{ Irrigation No. } & \multicolumn{1}{c|}{ Irrigation date, 2015 } & \multicolumn{1}{c|}{ Irrigation date, 2016 } \\
\hline $1^{\text {st }}$ irrigation (Sowing) & November 1, 2015 & November 3, 2016 \\
\hline $2^{\text {nd }}$ irrigation & December 22, 2015 & December 27, 2016 \\
\hline $3^{\text {rd }}$ irrigation & January 26, 2016 & January 29, 2017 \\
\hline $4^{\text {th }}$ irrigation & February 22, 2016 & February 25, 2017 \\
\hline $5^{\text {th }}$ irrigation & March 15, 2016 & March 18, 2017 \\
\hline
\end{tabular}

\section{Compaction unit:}

In order to study the effect of compaction the furrows on water advancing and water requirement, an iron frame has a specific dimensions was modified to be pulled by a two wheels-tractor has Diesel engine (ZH1100) as shown in Figs 2 and 3. The mentioned frame was made from iron angles of $50 \times 50 \times 5 \mathrm{~mm}$. The frame is loaded on two wheels which can rotate left and right, changing the direction of the tractor, also the frame has three hatch points; the lower two hatch points were combined in one link which connected with the drawbar of the tractor; where the top hatch point was connected with sub-link fixed on the main link to make a vertical balance for the frame. The driver's seat was fixed above the modified frame. Four weights of $20 \mathrm{~kg}$ for each one were distributed on the modified frame and the tractor to increase the total weight and stability. Some specifications of the modified frame and the used tractor were listed in Table 3.

Table 3. Specifications of compaction unit.

\begin{tabular}{clc} 
No. & \multicolumn{1}{c}{ Items } & Specifications \\
1 & Engine type & ZH1100 Chinese-made \\
2 & Engine power, kW & 11.03 \\
3 & Total length, cm & 230 \\
4 & Total width, cm & 140 \\
5 & Total height, cm & 100 \\
6 & Front wheels diameter, cm & 72 \\
7 & Rear wheels diameter, cm & 33 \\
8 & Total weight, $\mathrm{kg}$ & 300
\end{tabular}

The furrows were hoed and soil compaction was performed before second irrigation. The soil moisture content measured before compaction, it was 33.9, 35.2, 
36.1 and $36.7 \%$ for soil depths (0-15), (15-30), (30-45) and (45-60) cm, respectively. The speed of the compaction unit (modified reaper) at compaction event was about $5.0 \mathrm{~km} \mathrm{~h}^{-1}$. Irrigation of bed sowing shown in Fig. 4.

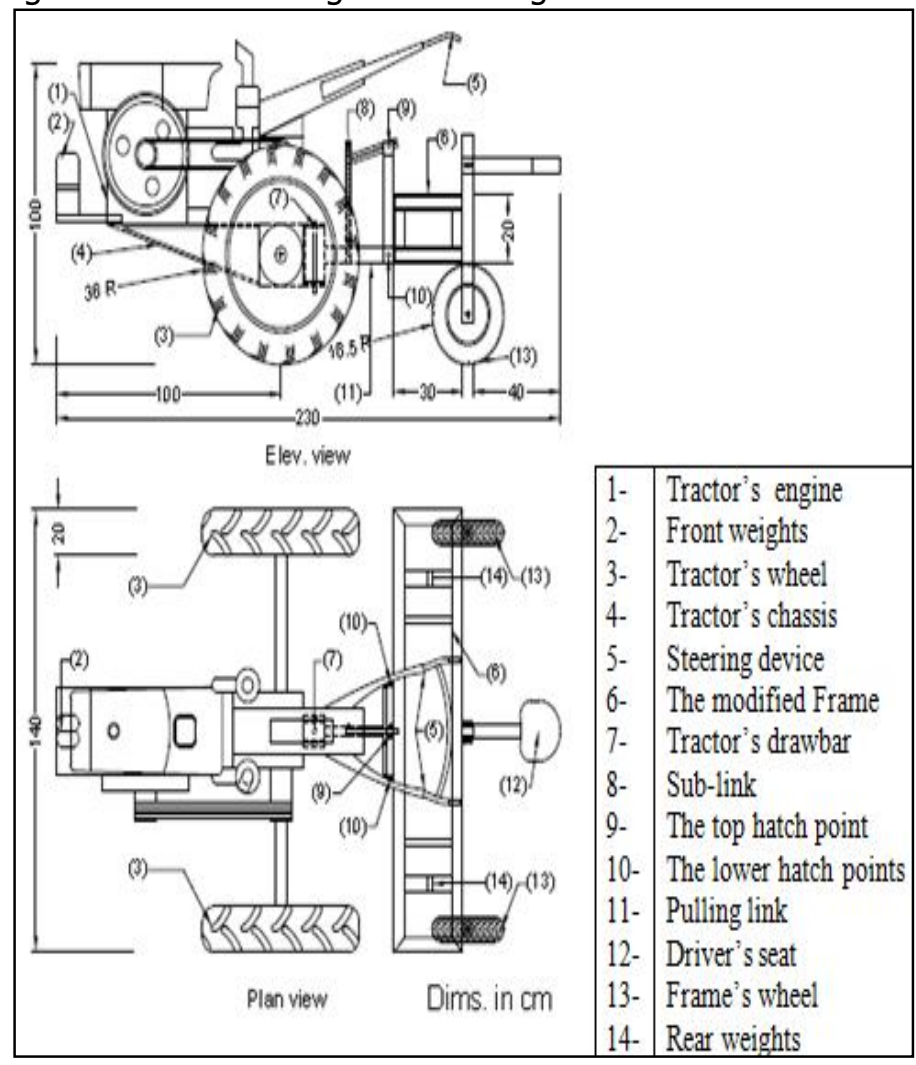

Fig. 2. Elevation and plan views of the modified frame connected with two wheels-tractor.

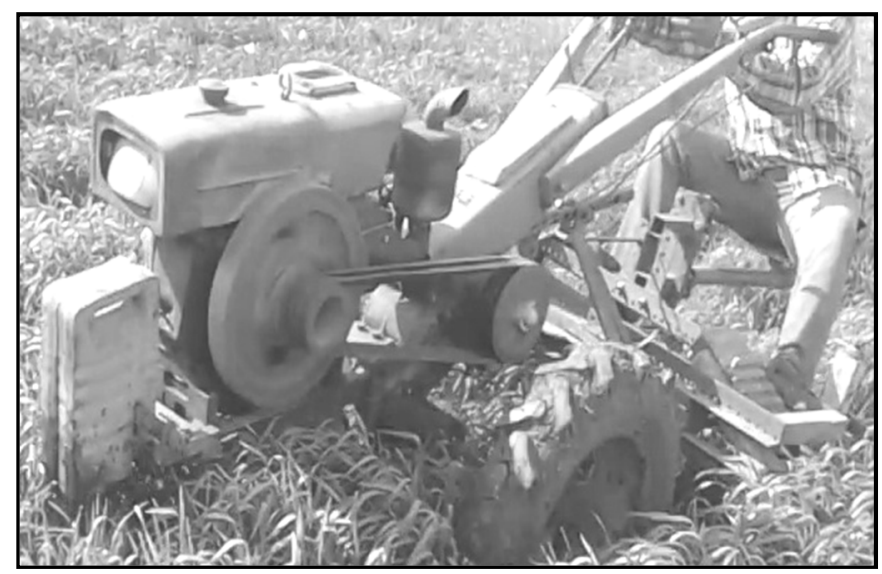

Fig. 3.Working of compaction unit. 


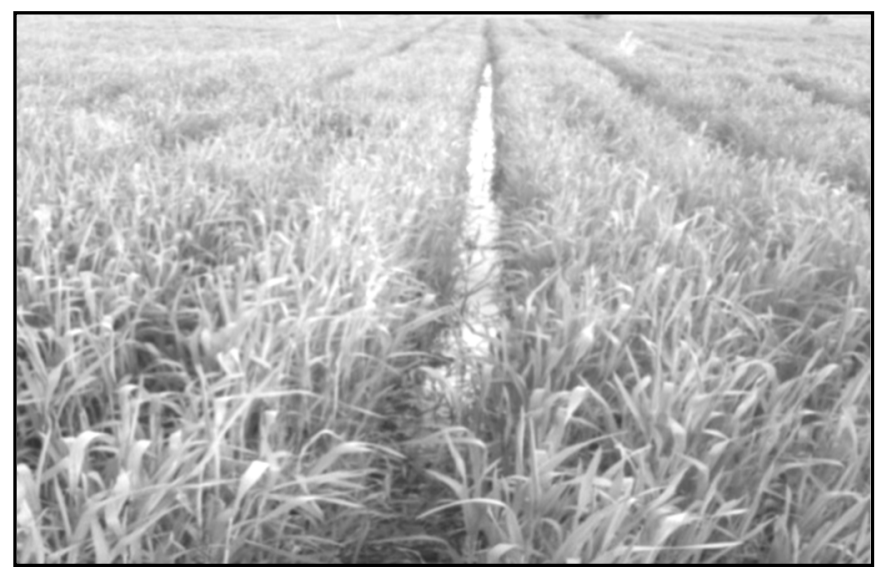

Fig. 4. Irrigation of wheat bed

\section{Perforated pipe system components:}

Perforated pipe system under study consisted of centrifugal water pump; some specifications of the pump were listed in Table 4.

Table 4: Specifications of centrifugal water pump.

\begin{tabular}{|c|l|c|}
\hline No. & \multicolumn{1}{|c|}{ Items } & Specifications \\
\hline 1 & Engine type & Four-stroke, Single-cylinder, Gasoline engine. \\
\hline 2 & Engine power, $\mathrm{kW}$ & $3.75 \mathrm{~kW}$ \\
\hline 3 & Diameter of inlet and outlet & 3 inch $(80 \mathrm{~mm})$ \\
\hline 4 & Max. delivery lift, $\mathrm{m}$ & 23 \\
\hline 5 & Suction height, $\mathrm{m}$ & 7 \\
\hline 6 & Max. water output, $\mathrm{m}^{3} \mathrm{~h}^{-1}$ & 30 \\
\hline 7 & Total weight, $\mathrm{kg}$ & 25 \\
\hline
\end{tabular}

Main control valve with $75 \mathrm{~mm}$ was used, $15 \mathrm{~m}$ of perforated Aluminum pipe had $75 \mathrm{~mm}$ outer diameter with circular orifices of $32 \mathrm{~mm}$ diameter distributed at $120 \mathrm{~cm}$ (the same distance between beds) were used; the pipes are available in $6 \mathrm{~m}$ length and use quick coupler with rubber ring jointing. The flow rate of every orifice was controlled by $32 \mathrm{~mm}$ PVC control valve which jointed with the orifice by PVC saddle (75 X $32 \mathrm{~mm}$ ); flow rate was measured by direct method (by measuring the time to fill a certain volume of a tin (James 1988)).

\section{Study variables:}

a. Wheat sowing pattern: two different sowing patterns; flat sowing (F) and bed sowing.

b. Furrow compaction: three levels of furrow compaction under bed sowing were applied; no compaction (NC), compaction one pass (C1) and compaction two passes (C2).

C. Flow rate: three values of flow rate were calibrated and applied; $0.4 \mathrm{~L} \mathrm{~s}^{-1}(\mathrm{Q} 1)$, $0.6 \mathrm{~L} \mathrm{~s}^{-1}(\mathrm{Q} 2)$ and $0.8 \mathrm{~L} \mathrm{~s}^{-1}(\mathrm{Q} 3)$. 
The study treatments and experimental field layout are shown in Fig. 5.

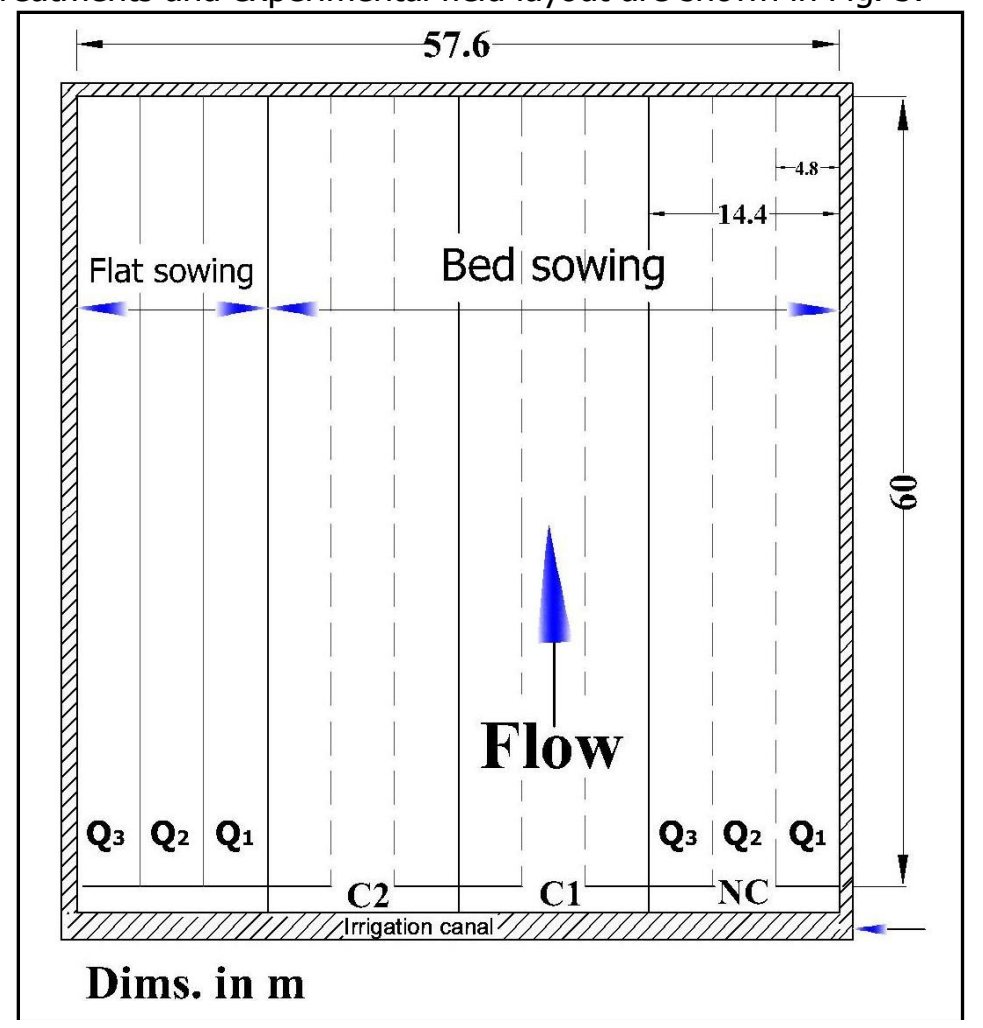

Fig. 5. Schematic diagram showing distribution of experimental treatments.

\section{Measurements:}

\section{Advance time}

Furrow length was divided into 6 equal stations by $10 \mathrm{~m}$ distance between each two successive stations. Advance time at every station was recorded.

\section{Total applied water}

Flow rate for each irrigation treatment was calibrated by direct method and total applied water at end of every furrow was calculated according to (Israelsen and Hanson, 1980).

$$
D=\frac{60 t Q}{L W}
$$

Where $D$ is depth of water applied (mm), $t$ is application time (min), $L$ is furrow length $(60 \mathrm{~m}), W$ is furrow spacing $(1.2 \mathrm{~m})$ and $Q$ is flow rate $\left(\mathrm{L} \mathrm{s}^{-1}\right)$.

\section{Stored water}

Soil samples were taken directly before and two days after irrigations, soil water content was computed using the gravimetric method and Equation (1) was applied.

$$
\theta_{w}=\left(W_{w}-W_{d}\right) / W_{d}
$$

Where $\theta_{w}$ is water content expressed on a dry weight basis (\%), $W_{d}$ is weight of dry soil ( $\mathrm{g}$ ) and $W_{w}$ is weight of wet soil $(\mathrm{g})$. Stored water in the root zone during irrigation event was calculated according to (Gudissa and Edossa 2014).

$$
Z_{\text {avg }}=\sum_{i=1}^{n} \frac{\theta_{A i-} \theta_{B i}}{100} \times D_{i} B_{i}
$$


Where $Z_{\text {avg }}$ is stored water $(\mathrm{cm}), i$ is number of soil layer, $\theta_{A i}$ is soil moisture content after irrigation for the specified soil layer $(\%), \theta_{\mathrm{Bi}}$ is soil moisture content before irrigation for the specified soil layer $(\%), \mathrm{D}_{\mathrm{i}}$ is depth of the soil layer within the root zone and $B_{i}$ is bulk density of the specified soil layer $\left(\mathrm{gm} \mathrm{cm}^{-3}\right)$.

\section{Application efficiency}

Water application efficiency ( $\left.E_{a}, \%\right)$ was estimated according to (James 1988).

$$
E_{a}=\frac{Z_{\text {avg }}}{D} \times 100
$$

Where $Z_{\text {avg }}$ is average depth of water stored in the root zone and $D$ is average depth of applied water.

\section{Water distribution efficiency}

Water distribution efficiency (WDE \%) was estimated according to (James 1988).

$$
W D E=100\left(1.0-\frac{\sum\left|x_{i-} x^{-}\right|}{n x^{-}}\right)
$$

Where $x_{i}$ is depth of water stored at point $i, x^{-}$is average depth of water stored along the furrow during the irrigation and $n$ is number of observations.

\section{Crop yield and its components}

At harvesting time, wheat grain yield, $\mathrm{kg} \mathrm{fed}^{-1}$ and some yield components such as 1000 grain weight, number of panicle $\mathrm{m}^{-2}$ and straw yield, $\mathrm{kg} \mathrm{fed}^{-1}$ calculated and recorded for all given treatments under study.

\section{Water productivity}

Water productivity (WP), $\mathrm{kg} \mathrm{m}^{-3}$ was calculated according to (Jensen 1980) as following

$$
W P=\frac{\text { Total grain yield, }\left(\mathrm{kg} \mathrm{fed}^{-1}\right)}{\text { Total applied irrigation water },\left(\mathrm{m}^{3} \mathrm{fed}^{-1}\right)}
$$

\section{Experimental design}

Statistical analysis was carried out by CoStat statistical software. Experimental design was randomized complete block design for flat sowing and split plot design for bed sowing treatments "flow rate in main plot and furrow compaction in sub plot".

\section{RESULTS AND DISCUSSION}

\section{Advance time}

An advance time was recorded at six stations along the furrow each irrigation along the season. The averages of advance time in relation to distance under different treatments for two growing seasons were shown in Fig. 6. The results indicated that, bed sowing had shorter advance time than flat sowing; under bed sowing increasing compaction level from NC to $\mathrm{C} 2$ decreased advance time, this may be due to low infiltration rate which occurred by compaction. Effect of compaction level on advance time was high at the beginning of the season and decreased gradually thereafter, these results are in agreement with that found by Montaserei et al. (2016). Under different sowing patterns and compaction levels, the advance time was almost similar at head end of the field and the difference increased with distance at tail end of the 
field. Increasing flow rate from 0.4 to $0.8 \mathrm{~L} \mathrm{~s}^{-1}$ decreased advance time either under flat or bed sowing. Bed sowing at no compaction decreased advance time by about $31.3,34.5$ and $32.8 \%$ compared with flat sowing under flow rates $0.4,0.6$ and $0.8 \mathrm{~L}$ $\mathrm{S}^{-1}$ respectively. Compaction one pass $\mathrm{C} 1$ decreased advance time by about $12.6,6.6$ and $1.6 \%$ compared with no compaction NC under flow rates $0.4,0.6$ and $0.8 \mathrm{~L} \mathrm{~s}^{-1}$ respectively, compaction two passes $\mathrm{C} 2$ decreased advance time by about 4.5, 2.7 and $12.5 \%$ compared with compaction one pass $\mathrm{C} 1$ under flow rates $0.4,0.6$ and 0.8 respectively. Compaction two passes $\mathrm{C} 2$ decreased advance time by about $42.7,40.2$ and $42.1 \%$ compared with flat sowing under flow rates $0.4,0.6$ and $0.8 \mathrm{~L} \mathrm{~s}^{-1}$ respectively. The highest advance time was $363 \mathrm{~min}$ which obtained by flat sowing and $0.4 \mathrm{~L} \mathrm{~s}^{-1}$ flow rate, while the lowest advance time was $91 \mathrm{~min}$ which obtained by bed sowing, compaction two passes $\mathrm{C} 2$ and flow rate $0.8 \mathrm{~L} \mathrm{~s}^{-1}$.

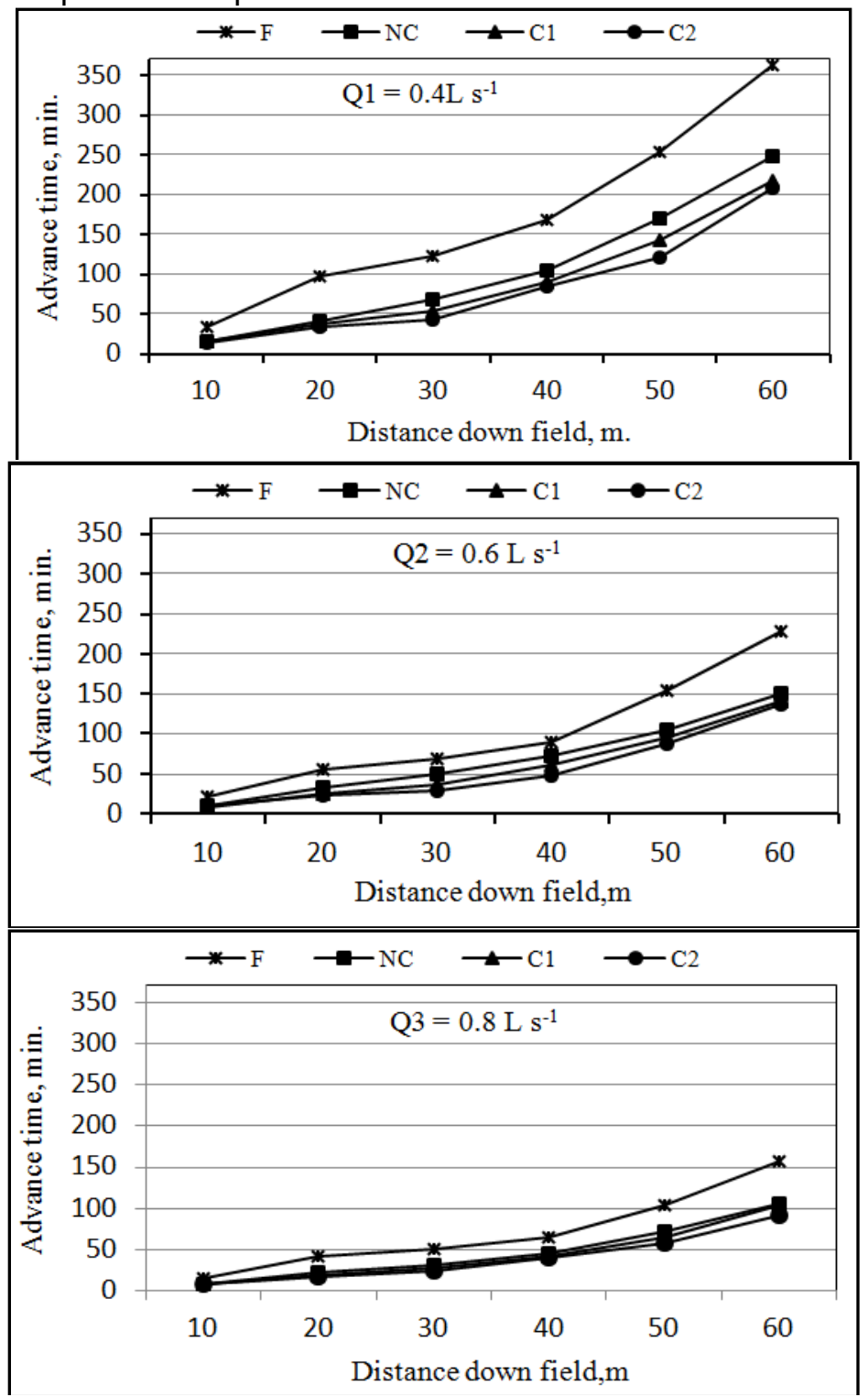

Fig. 6. Effect of sowing pattern, furrow compaction and flow rate on irrigation advance time. 
Statistical analysis indicated that, under bed sowing flow rate, compaction level and their interactions had a highly significant effect on advance time. Under flat sowing, discharge had a highly significant effect on advance time. Analysis of variance under bed sowing showed in table 5 . Under bed sowing, for sub main plot (compaction level) NC had the highest effect on advance time while $\mathrm{C} 2$ had the lowest effect. For main plot (discharge), Q1 had the highest effect on advance time, while Q3 had the lowest effect. Under flat sowing, Q1 had the highest effect on advance time, while Q3 had the lowest effect.

Table 5. Analysis of variance for advance time.

\begin{tabular}{|l|c|c|c|cc|}
\hline \multicolumn{1}{|c|}{ source } & df & SS & MS & \multicolumn{2}{c|}{ F } \\
\hline Replicates & 2 & 1.6 & 0.77 & 1.75 & ns \\
\hline Discharge (Q) & 2 & 72338 & 36169 & $81380.25 \quad * *$ \\
\hline Error (a) & 4 & 1.77 & 0.44 & & \\
\hline Compaction (C) & 2 & 2418 & 1209 & $989.2 \quad * *$ \\
\hline CX Q & 4 & 988 & 247 & 202.1 & $* *$ \\
\hline Error (b) & 12 & 14.66 & 1.22 & & \\
\hline \multicolumn{1}{|c|}{ Total } & 26 & 75762 & & & \\
\hline
\end{tabular}

LSD 0.05 for compaction $=1.14$

LSD 0.05 for discharge $=0.87$

\section{Total applied water}

An average of total applied water $\left(\mathrm{m}^{3} \mathrm{fed}^{-1}\right)$ at flat sowing and bed sowing with its compaction levels in relation to flow rate for two growing seasons were shown in Fig 7. The results indicated that, bed sowing led to less amount of applied water compared with flat sowing, where advance time decreased. Under bed sowing increasing compaction level from NC to $\mathrm{C} 2$ led to decrease total applied water, these results may be explicate as bed sowing decreased irrigation losses compared with flat sowing. Increasing flow rate from 0.4 to $0.8 \mathrm{~L} \mathrm{~s}^{-1}$ decreased total applied water under flat and sowing treatments. Bed sowing at no compaction NC decreased total applied water by about $26.0,28.1$ and $26.1 \%$ compared with flat sowing under flow rates $0.4,0.6$ and $0.8 \mathrm{~L} \mathrm{~s}^{-1}$ respectively. Under bed sowing, compaction one pass C1 decreased total applied water by about 9.3, 4.8 and $1.1 \%$ compared with no compaction NC under flow rates $0.4,0.6$ and $0.8 \mathrm{~L} \mathrm{~s}^{-1}$ respectively, compaction two passes "C2" decreased total applied water by about 3.5, 1.8 and $8.9 \%$ compared with compaction one pass $\mathrm{C} 1$ under flow rates $0.4,0.6$ and $0.8 \mathrm{~L} \mathrm{~s}^{-1}$ respectively.

The results showed that using bed sowing and furrow compaction two passes "C2" saved irrigation water by about $35.3,32.8$ and $33.3 \%$ per feddan compared with flat sowing under three different flow rates respectively. The result revealed that flat sowing received more amounts of irrigation water than bed sowing in the three cases of flow rates due to increase advance time under flat sowing along the furrow length. 
The lowest total applied water was $1346 \mathrm{~m}^{3} \mathrm{fed}^{-1}$. obtained under bed sowing at $\mathrm{C}_{2} \mathrm{Q}_{3}$ treatment, while the highest total applied water was $2278 \mathrm{~m}^{3} \mathrm{fed}^{-1}$. obtained under flat sowing at $\mathrm{FQ}_{1}$ treatment.

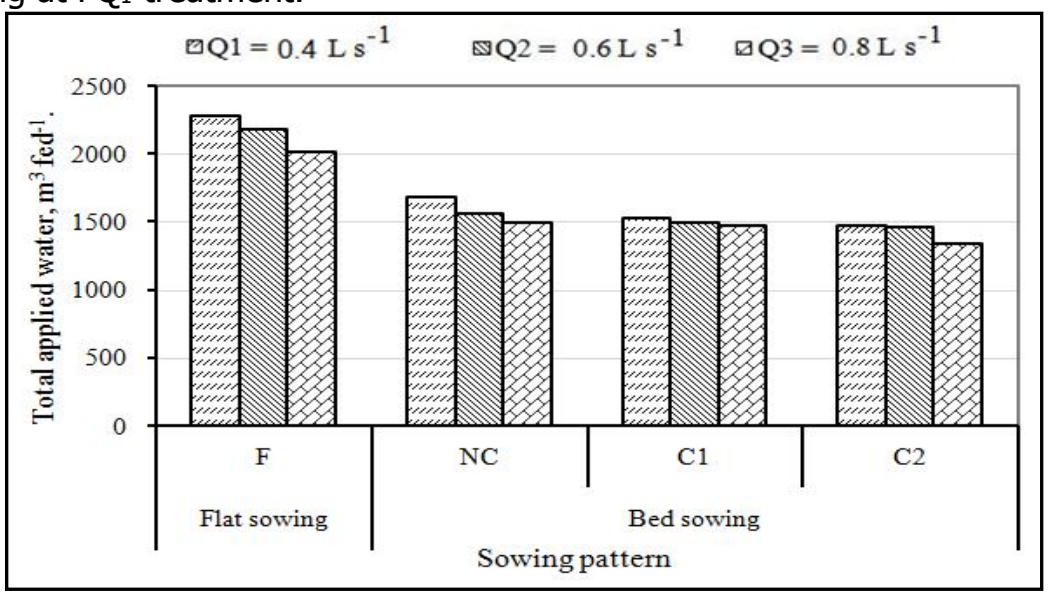

Fig. 7. Effect of sowing pattern, furrow compaction and flow rate on total applied water.

Data analysis indicated that, under bed sowing flow rate, compaction level and their interactions had a highly significant effect on total applied water. Under flat sowing, discharge had a highly significant effect on total applied water. Analysis of variance under bed sowing showed in table 6 . Under bed sowing, for sub main plot (compaction level) NC had the highest effect on total applied water, while C2 had the lowest effect. For main plot (discharge), Q1 had the highest effect on total applied water, while Q3 had the lowest effect. Under flat sowing, Q1 had the highest effect on total applied water, while Q3 had the lowest effect.

Table 6. Analysis of variance for total applied water.

\begin{tabular}{|l|c|c|c|cc|}
\hline \multicolumn{1}{|c|}{ source } & df & SS & MS & \multicolumn{2}{c|}{ F } \\
\hline Replicates & 2 & 1.6 & 0.77 & 1.75 & ns \\
\hline Discharge (Q) & 2 & 69458.7 & 34729.3 & $78141 \quad * *$ \\
\hline Error (a) & 4 & 1.77 & 0.44 & & \\
\hline Compaction (C) & 2 & 105122.7 & 52561.3 & $236526 \quad * *$ \\
\hline CX Q & 4 & 21963.3 & 5490.8 & 24708.8 & $* *$ \\
\hline Error (b) & 12 & 2.7 & 0.22 & & \\
\hline \multicolumn{1}{|c|}{ Total } & 26 & 196550.7 & & & \\
\hline
\end{tabular}

LSD 0.05 for compaction $=0.48$

LSD 0.05 for discharge $=0.87$

\section{Application efficiency}

The average depths of irrigation water stored in the root zone for different treatments depending on soil moisture content before and after irrigation for four events were listed in Table 7. 
Table 7. Average depths of water stored in the root zone for different treatments, $\mathrm{m}^{3} \mathrm{fed}^{-1}$.

\begin{tabular}{|c|c|c|c|c|}
\hline \multirow{2}{*}{ Sowing method } & \multirow{2}{*}{ Furrow compaction } & \multicolumn{3}{|c|}{ Flow rate, $\mathrm{L} \mathrm{s}^{-1}$} \\
\cline { 3 - 5 } & & 0.4 & 0.6 & 0.8 \\
\hline \multirow{2}{*}{ Flat sowing } & F & 1070 & 1073 & 1046 \\
\hline \multirow{3}{*}{ Bed sowing } & NC & 790 & 788 & 767 \\
\cline { 2 - 5 } & C1 & 728 & 741 & 757 \\
\cline { 2 - 5 } & C2 & 700 & 726 & 713 \\
\hline
\end{tabular}

An average of application efficiency "Ea \%" at flat sowing and bed sowing with its compaction levels in relation to flow rate for two growing seasons for four events were shown in Fig 8. The results indicated that, bed sowing increased application efficiency comparing with flat sowing, under bed sowing increasing compaction level from NC to C2 increased application efficiency. These results are due to reduce seasonal applied water and increase stored water by compaction. Increasing flow rate from 0.4 to $0.8 \mathrm{~L} \mathrm{~s}^{-1}$ increased application efficiency under flat and bed sowing, where seasonal applied water decreased. Bed sowing at no compaction NC increased application efficiency by $7.8,12.1$ and $8.7 \%$ compared with flat sowing under flow rates $0.4,0.6$ and $0.8 \mathrm{~L} \mathrm{~s}^{-1}$ respectively. Increasing compaction level from NC to C1 increased application efficiency by $5.0,0.6$ and $0.2 \%$ for flow rates $0.4,0.6$ and $0.8 \mathrm{~L}$ $\mathrm{S}^{-1}$ respectively. Increasing compaction level from C1 to C2 increased application efficiency by $0.9,0.4$ and $7.3 \%$ for flow rates $0.4,0.6$ and $0.8 \mathrm{~L} \mathrm{~s}^{-1}$ respectively. C2 treatments increased application efficiency by $14.2,13.1$ and $16.7 \%$ for flow rates $0.4,0.6$ and $0.8 \mathrm{~L} \mathrm{~s}^{-1}$ respectively comparing with $\mathrm{F}$ treatments. The results indicated that using bed sowing and furrow compaction two passes "C2" under three different flow rates increased application efficiency by $14.7 \%$ in average comparing with $F$ treatments. The highest application efficiency was $75.4 \%$ obtained at $\mathrm{C}_{2} \mathrm{Q}_{3}$ treatment, while the lowest one was $57 \%$ obtained at $\mathrm{FQ}_{1}$ treatment.

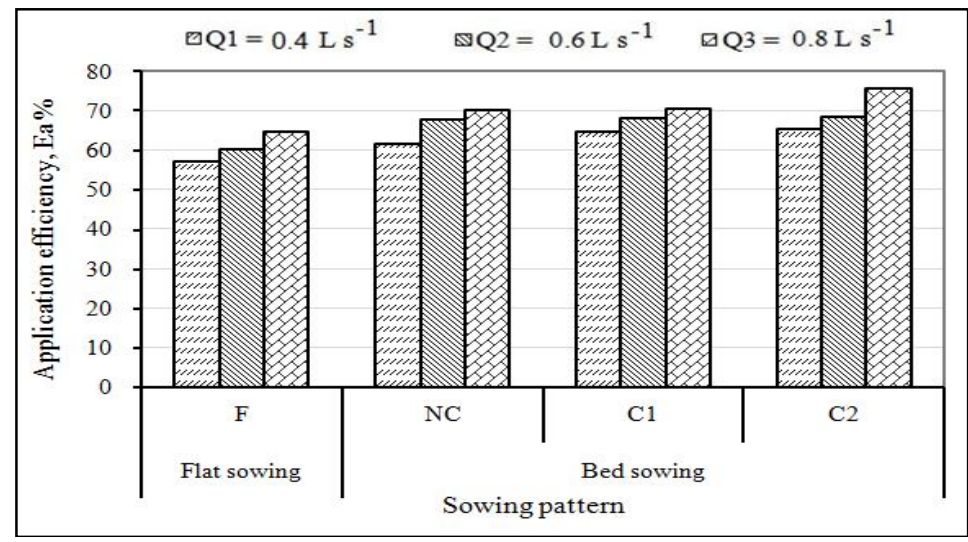

Fig. 8. Effect of sowing pattern, furrow compaction and flow rate on application efficiency. 
Also, data analysis indicated that, under bed sowing; flow rate, compaction level and their interactions had a highly significant effect on application efficiency. Under flat sowing, discharge had a highly significant effect on application efficiency. Analysis of variance under bed sowing showed in table 8 . Under bed sowing, for sub main plot (compaction level) C2 had the highest effect on application efficiency while NC had the lowest effect. For main plot (discharge), Q3 had the highest effect on application efficiency, while Q1 had the lowest effect. Under flat sowing, Q3 had the highest effect on application efficiency, while Q1 had the lowest effect.

Table 8. Analysis of variance for application efficiency.

\begin{tabular}{|l|c|c|c|cc|}
\hline \multicolumn{1}{|c|}{ source } & df & SS & MS & \multicolumn{2}{c|}{ F } \\
\hline Replicates & 2 & 0.45 & 0.22 & $9.18 \quad$ ns \\
\hline Discharge (Q) & 2 & 303.6 & 151.8 & 6257 ** \\
\hline Error (a) & 4 & 0.1 & 0.024 & & \\
\hline Compaction (C) & 2 & 42.66 & 21.33 & $300.73 \quad * *$ \\
\hline CXQ & 4 & 30.76 & 7.7 & $108.41 \quad * *$ \\
\hline Error (b) & 12 & 0.85 & 0.07 & & \\
\hline \multicolumn{1}{|c|}{ Total } & 26 & 378.4 & & & \\
\hline
\end{tabular}

LSD 0.05 for compaction $=0.27$

LSD 0.05 for discharge $=0.2$

\section{Water distribution efficiency}

An average of water distribution efficiency at flat sowing and bed sowing with its compaction levels in relation to flow rate for two growing seasons were shown in Fig. 9. The results indicated that, bed sowing increased water distribution efficiency comparing with flat sowing. Under bed sowing increasing compaction level from NC to C2 increased water distribution efficiency. These results are due to decrease the variance in stored water along the field by compaction. Increasing flow rate from 0.4 to $0.8 \mathrm{~L} \mathrm{~s}^{-1}$ increased water distribution efficiency under flat and bed sowing. Bed sowing at no compaction NC increased water distribution efficiency by 1.9, 2.6 and $2.9 \%$ compared with flat sowing under flow rates $0.4,0.6$ and $0.8 \mathrm{~L} \mathrm{~s}^{-1}$ respectively. Increasing compaction level from NC to $\mathrm{C} 1$ increased water distribution efficiency by 6.7, 5.6 and $5.2 \%$ for flow rates $0.4,0.6$ and $0.8 \mathrm{~L} \mathrm{~s}^{-1}$ respectively. Increasing compaction level from $\mathrm{C} 1$ to $\mathrm{C} 2$ increased water distribution efficiency by $2.6,3.5$ and $3.6 \%$ for flow rates $0.4,0.6$ and $0.8 \mathrm{~L} \mathrm{~s}^{-1}$ respectively. $\mathrm{C} 2$ treatments increased water distribution efficiency by $11.6,12.1$ and $12.1 \%$ for flow rates $0.4,0.6$ and $0.8 \mathrm{~L} \mathrm{~s}^{-1}$ respectively comparing with " $F$ " treatments. The results indicated that using bed sowing and furrow compaction two passes "C2" under three different flow rates increased water distribution efficiency by about $11.9 \%$ in average comparing with $\mathrm{F}$ treatments. The highest water distribution efficiency was $83.1 \%$ obtained at $\mathrm{C}_{2} \mathrm{Q}_{3}$ treatment, while the lowest one was $66.7 \%$ obtained at $\mathrm{FQ}_{1}$ treatment. 


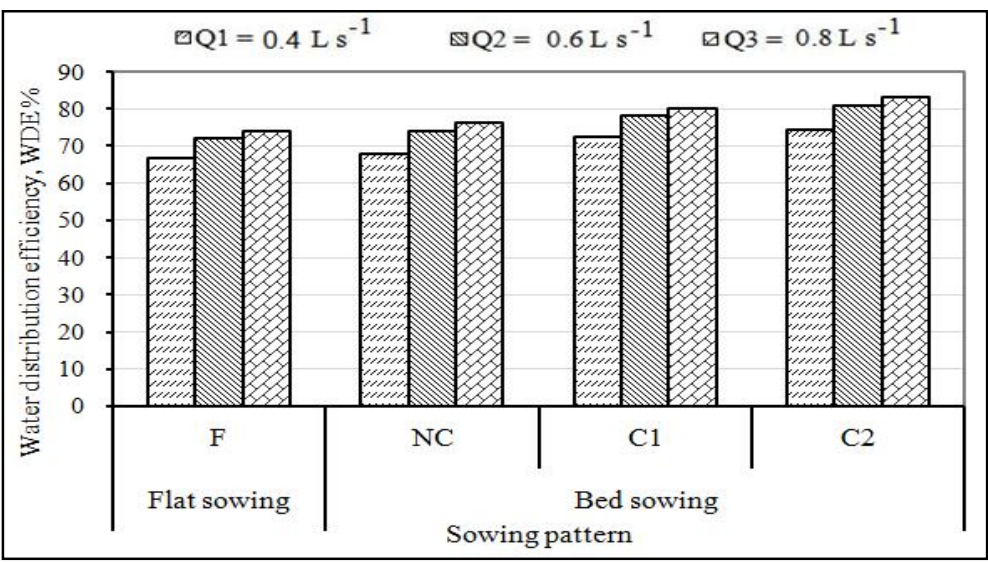

Fig. 9. Effect of sowing pattern, furrow compaction and flow rate on water distribution efficiency.

So, data analysis indicated that, under bed sowing flow rate and compaction level had a highly significant effect on water distribution efficiency while their interactions had a significant effect. Under flat sowing, discharge had a highly significant effect on water distribution efficiency. Analysis of variance under bed sowing showed in table 9. Under bed sowing, for sub main plot (compaction level) C2 had the highest effect on water distribution efficiency while NC had the lowest effect. For main plot (discharge), Q3 had the highest effect on water distribution efficiency, while Q1 had the lowest effect. Under flat sowing, Q3 had the highest effect on water distribution efficiency, while Q1 had the lowest effect.

Table 9. Analysis of variance for water distribution efficiency.

\begin{tabular}{|l|c|c|c|cc|}
\hline \multicolumn{1}{|c|}{ source } & $\mathrm{df}$ & $\mathrm{SS}$ & $\mathrm{MS}$ & \multicolumn{2}{c|}{$\mathrm{F}$} \\
\hline Replicates & 2 & 0.31 & 0.16 & $1.15 \quad$ ns \\
\hline Discharge (Q) & 2 & 338.5 & 169.3 & $1245.2 \quad * *$ \\
\hline Error (a) & 4 & 0.54 & 0.14 & & \\
\hline Compaction (C) & 2 & 204.61 & 102.3 & $2340.8 \quad * *$ \\
\hline CX Q & 4 & 0.76 & 0.19 & $4.35 \quad *$ \\
\hline Error (b) & 12 & 0.52 & 0.044 & & \\
\hline \multicolumn{1}{|c|}{ Total } & 26 & 545.3 & & & \\
\hline
\end{tabular}

LSD 0.05 for compaction $=0.215$

LSD 0.05 for discharge $=0.483$

\section{Crop yield and its components}

\section{a. Wheat grain yield}

An average of wheat grain yield at flat sowing and bed sowing with its compaction levels in relation to flow rate for two growing seasons were shown in Fig. 10. The results indicated that, bed sowing increased wheat grain yield comparing with flat sowing. Increasing flow rate from 0.4 to $0.8 \mathrm{~L} \mathrm{~s}^{-1}$ increased wheat grain yield under flat and bed sowing. Under bed sowing increasing compaction level from NC to C2 increased wheat grain yield; where, the compaction Encourages lateral movement of irrigation water through the beds and thus irrigating the wheat rows over the beds 
sufficiently. Bed sowing at no compaction NC increased wheat grain yield by 4.9, 5.9 and $4.7 \%$ compared with flat sowing under flow rates $0.4,0.6$ and $0.8 \mathrm{~L} \mathrm{~s}^{-1}$ respectively. Increasing compaction level from $\mathrm{NC}$ to $\mathrm{C} 1$ increased wheat grain yield by $7.1,2.6$ and $2.2 \%$ for flow rates $0.4,0.6$ and $0.8 \mathrm{~L} \mathrm{~s}^{-1}$ respectively. Increasing compaction level from $\mathrm{C} 1$ to $\mathrm{C} 2$ increased wheat grain yield by $0.13,2.6$ and $3.9 \%$ for flow rates $0.4,0.6$ and $0.8 \mathrm{~L} \mathrm{~s}^{-1}$ respectively. C2 treatments increased wheat grain yield by $12.5,11.5$ and $11.1 \%$ for flow rates $0.4,0.6$ and $0.8 \mathrm{~L} \mathrm{~s}^{-1}$ respectively comparing with $\mathrm{F}$ treatments.

The results indicated that using bed sowing and furrow compaction two passes "C2" under three different flow rates increased wheat grain yield by $11.7 \%$ in average comparing with $\mathrm{F}$ treatments. The highest wheat grain yield was $3100 \mathrm{~kg} \mathrm{fed}^{-1}$. obtained at $\mathrm{C}_{2} \mathrm{Q}_{3}$ treatment, while the lowest wheat grain yield was $2125 \mathrm{~kg} \mathrm{fed}^{-1}$. obtained at $\mathrm{FQ}_{1}$ treatment.

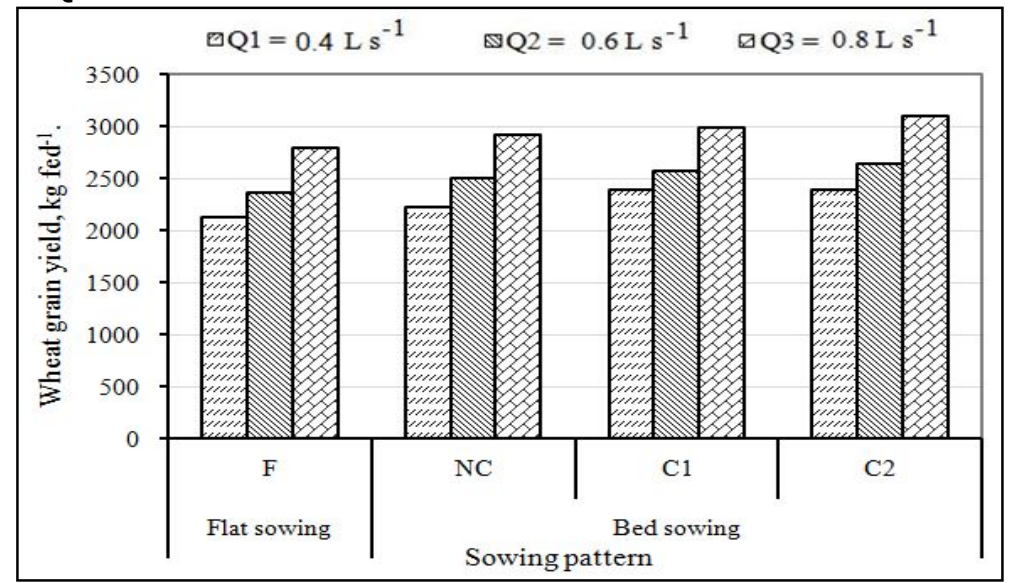

Fig. 10. Effect of sowing pattern, furrow compaction and flow rate on wheat grain yield.

Statistical analysis indicated that, under bed sowing flow rate, compaction level and their interactions had a highly significant effect on grain yield. Under flat sowing, discharge had a highly significant effect on grain yield. Analysis of variance under bed sowing showed in table 10. Under bed sowing, for sub main plot (compaction level) C2 had the highest effect on grain yield while NC had the lowest effect. For main plot (discharge) Q3 had the highest effect on grain yield, while Q1 had the lowest effect. Under flat sowing, Q3 had the highest effect on grain yield, while Q1 had the lowest effect. 
Table 10. Analysis of variance for water distribution efficiency.

\begin{tabular}{|l|c|c|c|cc|}
\hline \multicolumn{1}{|c|}{ source } & df & SS & MS & \multicolumn{2}{c|}{ F } \\
\hline Replicates & 2 & 0.074 & 0.04 & 0.25 & ns \\
\hline Discharge (Q) & 2 & 2059612 & 1029806 & 6951193 & $* *$ \\
\hline Error (a) & 4 & 0.6 & 0.14 & & \\
\hline Compaction (C) & 2 & 112329 & 56164.7 & 336988.2 & $* *$ \\
\hline CX Q & 4 & 13276.6 & 3319.1 & 19914.9 & $* *$ \\
\hline Error (b) & 12 & 2 & 0.17 & & \\
\hline \multicolumn{1}{|c|}{ Total } & 26 & 2185221.41 & & & \\
\hline
\end{tabular}

LSD 0.05 for compaction $=0.42$

LSD 0.05 for discharge $=0.5$

\section{b. Yield components}

Effect of sowing method, furrow compaction and flow rate on yield components (1000 grain weight $(\mathrm{g})$, number of panicle $\mathrm{m}^{-2}$ and straw yield $\left(\mathrm{kg} \mathrm{fed}^{-1}\right)$ ) are listed in Table 11. Bed sowing increased yield components comparing with flat sowing. Increasing flow rate from 0.4 to $0.8 \mathrm{~L} \mathrm{~s}^{-1}$ increased yield components under flat and bed sowing. Under bed sowing increasing compaction level from NC to C2 increased yield components. The highest yield components were $57 \mathrm{~g}, 389$ panicle $\mathrm{m}^{-2}$ and 7290 $\mathrm{kg} \mathrm{fed}^{-1}$. for 1000 grain weight, number of panicle $\mathrm{m}^{-2}$ and straw yield respectively which obtained by $\mathrm{C}_{2} \mathrm{Q}_{3}$ treatment, while the lowest value were $43 \mathrm{~g}, 285$ panicle $\mathrm{m}^{-2}$ and $5030 \mathrm{~kg} \mathrm{fed}^{-1}$. which obtained by $\mathrm{FQ}_{1}$ treatment.

Table 11. Effect of sowing method, furrow compaction and flow rate on yield components.

\begin{tabular}{|c|c|c|c|c|}
\hline \multirow{2}{*}{$\begin{array}{l}\text { Sowing } \\
\text { pattern }\end{array}$} & \multirow{2}{*}{ Yield components } & \multicolumn{3}{|c|}{ Flow rate, $\mathrm{L} \mathrm{s}^{-1}$} \\
\hline & & 0.4 & 0.6 & 0.8 \\
\hline \multirow{3}{*}{$F$} & 1000 grain weight, $\mathrm{g}$ & 43 & 46 & 48 \\
\hline & number of panicle $\mathrm{m}^{-2}$ & 285 & 295 & 322 \\
\hline & straw yield, kg fed ${ }^{-1}$ & 5030 & 5200 & 6200 \\
\hline \multirow{3}{*}{ NC } & 1000 grain weight, $\mathrm{g}$ & 46 & 48 & 50 \\
\hline & number of panicle $\mathrm{m}^{-2}$ & 328 & 337 & 338 \\
\hline & straw yield, $\mathrm{kg} \mathrm{fed}^{-1}$ & 5450 & 6000 & 6260 \\
\hline \multirow{3}{*}{$\mathrm{C} 1$} & 1000 grain weight, $\mathrm{g}$ & 49 & 51 & 54 \\
\hline & number of panicle $\mathrm{m}^{-2}$ & 348 & 350 & 369 \\
\hline & straw yield, kg fed ${ }^{-1}$ & 6300 & 6860 & 6940 \\
\hline \multirow{3}{*}{$\mathrm{C} 2$} & 1000 grain weight, $\mathrm{g}$ & 52 & 53 & 57 \\
\hline & number of panicle $\mathrm{m}^{-2}$ & 365 & 379 & 389 \\
\hline & straw yield, kg fed ${ }^{-1}$ & 6300 & 7146 & 7290 \\
\hline
\end{tabular}

6. Water productivity: An average of water productivity at flat sowing and bed sowing with its compaction levels in relation to flow rate for two growing seasons were shown in Fig. 11. The results indicated that, bed sowing increased water productivity compared with flat sowing. Increasing flow rate from 0.4 to $0.8 \mathrm{~L} \mathrm{~s}^{-1}$ 
increased water productivity under flat and bed sowing, under bed sowing increasing compaction level from NC to C2 increased water productivity, where applied water decreased and wheat grain yield increased. Bed sowing at no compaction NC increased water productivity by $41.8,47.5$ and $41.6 \%$ compared with flat sowing under flow rates $0.4,0.6$ and $0.8 \mathrm{~L} \mathrm{~s}^{-1}$ respectively. Increasing compaction level from NC to $\mathrm{C} 1$ increased water productivity by $18.1,7.8$ and $3.3 \%$ for flow rates $0.4,0.6$ and $0.8 \mathrm{~L} \mathrm{~s}^{-1}$ respectively. Increasing compaction level from C1 to C2 increased water productivity by $3.7,4.4$ and $14 \%$ for flow rates $0.4,0.6$ and $0.8 \mathrm{~L} \mathrm{~s}^{-1}$ respectively. C2 treatments increased water productivity by $73.7,65.9$ and $66.7 \%$ for flow rates 0.4 , 0.6 and $0.8 \mathrm{~L} \mathrm{~s}^{-1}$ respectively comparing with $\mathrm{F}$ treatments.

The results indicated that using bed sowing and furrow compaction two passes "C2" under three different flow rates increased water productivity by $68.8 \%$ in average comparing with $\mathrm{F}$ treatments. The highest water productivity was $2.3 \mathrm{~kg} \mathrm{~m}^{-3}$. obtained at $\mathrm{C} 2 \mathrm{Q}_{3}$ treatment, while the lowest water productivity was $0.93 \mathrm{~kg} \mathrm{~m}^{-3}$. obtained at $\mathrm{FQ}_{1}$ treatment.

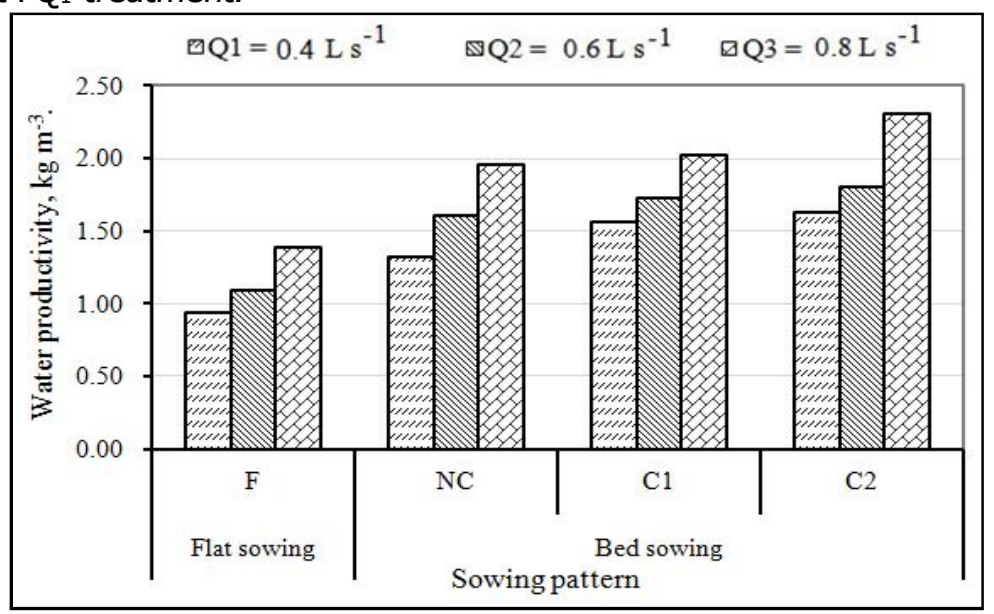

Fig. 11. Effect of sowing pattern, furrow compaction and flow rate on water productivity.

Data analysis indicated that, under bed sowing flow rate, compaction level and their interactions had a highly significant effect on grain yield. Under flat sowing, discharge had a highly significant effect on grain yield. Analysis of variance under bed sowing showed in table 12. Under bed sowing, for sub main plot (compaction level) C2 had the highest effect on water productivity while NC had the lowest effect. For main plot (discharge) Q3 had the highest effect on water productivity, while Q1 had the lowest effect. Under flat sowing, Q3 had the highest effect on water productivity, while Q1 had the lowest effect. 
Table 12. Analysis of variance for water productivity.

\begin{tabular}{|l|c|c|c|cc|}
\hline \multicolumn{1}{|c|}{ source } & df & SS & MS & \multicolumn{2}{c|}{ F } \\
\hline Replicates & 2 & 0.0025 & 0.0012 & $0.24 \quad$ ns \\
\hline Discharge (Q) & 2 & 1.7 & 0.83 & $1617.4 \quad * *$ \\
\hline Error (a) & 4 & 0.002 & 2.15 & & \\
\hline Compaction (C) & 2 & 0.38 & 0.19 & $144.5 \quad * *$ \\
\hline CX Q & 4 & 0.07 & 0.017 & $13.25 \quad * *$ \\
\hline Error (b) & 12 & 0.016 & 0.0013 & & \\
\hline \multicolumn{1}{|c|}{ Total } & 26 & 2.14 & & & \\
\hline
\end{tabular}

\section{CONCLUSION}

Generally, bed sowing advanced faster than the flat sowing. From the respective bed sowing treatments, bed sowing method, performed better in reaching the tail end of the furrow with advance time less compared with the respective flat sowing method. Flow rate, sowing method, compaction level and their interaction were found to be statistically significantly affecting the application efficiency, stored water and application uniformity. Furrow compaction technique enhanced grain yield and water productivity comparing with flat sowing method. Furrow compaction under bed sowing was found to perform better than flat sowing in terms of water saving and grain yield. It can be applied by farmers in case of limiting of irrigation water.

\section{REFERENCES}

1. Akbar, G.; M. M. Ahmad; M. Khan and M. Asif. 2017. Furrow lateral wetting potential for optimizing bed width in silty clay. Irrig. and Drain. 66: 218-226.

2. Ali, M. H. 2011. Practices of Irrigation and On-farm Water Management: Volume 2. Springer New York Dordrecht Heidelberg London. ISBN 978-1-4419-7636-9: 571.

3. Black, C. A., D. D. Evans, L. E. Ensminger, and R. C. Dinauer. 1965. Methods of Analysis (part1). American society of Agronomy, Inc. publisher. Modison, Wisconsin, U.S.A.

4. Beutler, A. N.; J. F. Centurion; A. P. Silva; M. A. C. Centurion; C. L. Leonel and O. S. Freddi. 2008. Soil compaction by machine traffic and least limiting water range related to soybean yield. Pesq. agropec. bras., Brasília, Vol. 43, no.11, p.1591-1600. 
5. El-Sayed, M. O. 2015. Performance of some new wheat cultivars under different irrigation regimes and sowing methods. . Ph. D. Thesis, Fac. of Agric., Tanta Univ., Egypt, $101 \mathrm{p}$.

6. Fahong, W.; W. Xuqing and K. Sayre. 2004. Comparison study on two different planting systems for winter wheat. Field Crops Res., 87 (1): 35-42.

7. Gudissa, H. D. and D. C. Edossa. 2014. Evaluation of surge and cutback flow furrow irrigation systems for pepper (capsicum annuum) production. Irrig. and Drain. 63: 463-473.

8. Hossain, M. I.; K. D. Sayre; R. K. Gupta; J. M. Duxbury and M. E. Haque. 2009. Performance of different wheat genotypes under different tillage options. Int. J. of Sustain. Crop Prod., 4(6): 17-21.

9. Israelsen O. W. and V. E. Hanson. 1980. Irrigation Principles and Practices. John Wiley \& Sons, Inc.: New York, London.

10. James, L. G. 1988. Principles of farm irrigation system design. John Willey/Sons (ed.), New York, pp. 543.

11. Jensen, M. E. 1980. Design and operation of farm irrigation system. ASAE, Monogr. 3, ASAE., St. Joseph, Ml, p 829.

12. Kirnak, H.; E. Doğan; O. Çopur and Z. Gökalp. 2013. Irrigation and yield parameters of soybean as effected by irrigation management, soil compaction and nitrogen fertilization. Journal of Agricultural Sciences, 19: 297-309.

13. Montaserei, M.; A. Nourjou and J. Behmanesh. 2016. Impacts of furrow firming and sowing pattern of sugar beet on improving water productivity. $2^{\text {nd }}$ World Irrigation Forum (WIF2). 6-8 November, Chiang Mai, Thailand, $6 \mathrm{p}$.

14. Mushtaq, A.; L. Ali; M. Q. Waqar and M. A. Ali. 2012. Bed planting: a new crop establishment method for wheat (Triticum aestivum L.) in cotton-wheat cropping system of southern Punjab. Int. J. of Agric. Appl. Sci., 4 (1): 8-14.

15. Sorour, S. GH. R.; A. Y. Ragab; H. A. Abdel-Raheem and A. M. I. Meleha. 2016. Effect of irrigation water management on wheat yield. J. of Soil Sci. and Agric. Eng., Mansoura Univ., 7 (5): 375 - 382.

16. Yonts, C. D. and D. E. Eisenhauer. 2007. Firming irrigation furrows to improve irrigation performance. Published by university of Nebraska-Lincoln extension, institute of agriculture and natural resources. http://extension.unl. edu/publications. 4 p. 


\title{
تأثير كبس خطوط الري على إنتاجية القـح المنزرع على مصاطب
}

\author{
طارق محمود عطافي' وليد البنداري الفخراني'

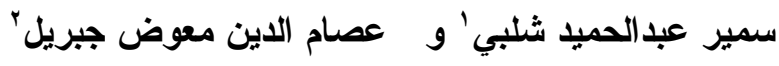

$$
\text { ' معهُ بحوث الهندسة الزراعية - مركز البحوث الزراعية - مصر. }
$$

أجريت در سة حقلية بمحطة البحوث الزر اعية بالجميزة محافظة الغربية - وسط الدلتا - مصر

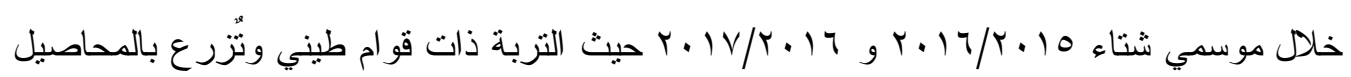
الحقلية وذللك بهدف تقدير إلى أي مدى يمكن لطريقة الزر اعة وكبس الخطوط و التصرف تحسين أداء

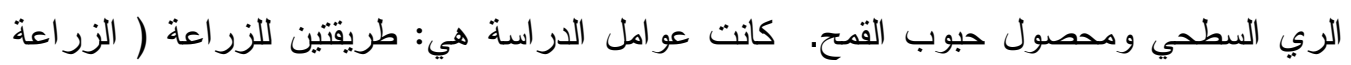

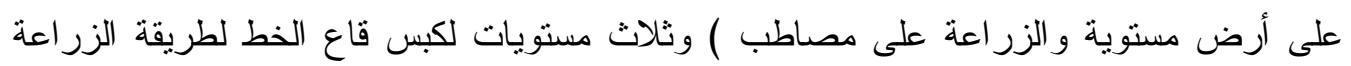
على مصاطب (خطوط بدون كبس ، كبس الخطوط مرة واحد ، كبس الخطوط مرتين) وثناث

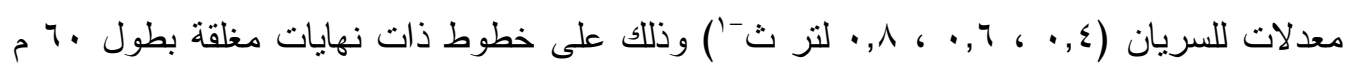

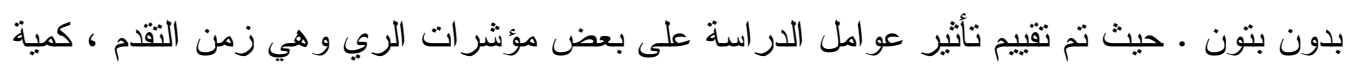

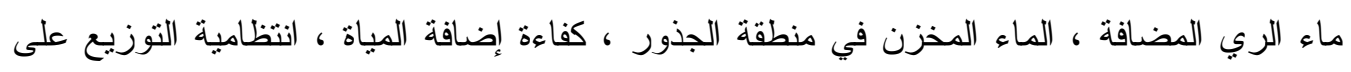

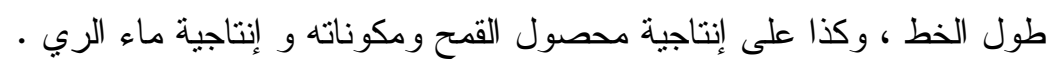
أنثارت أهم النتائج المتحصل عليها الى الى الآتي: 1- معدل نقدم الماء داخل الحقل كان اسرع مع طريقة الزراعة على مصاطب مقارنة

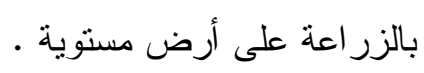

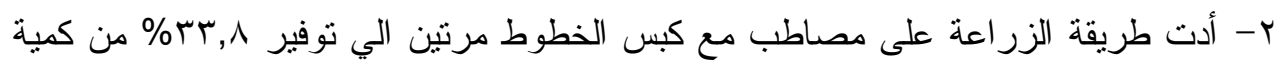

$$
\text { ماء الري مقارنة بالزر اعة على أرض مستوية. }
$$

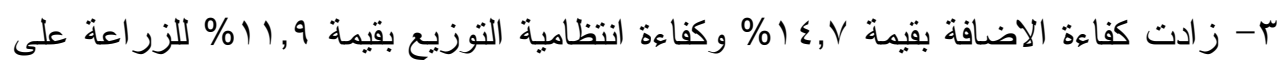

مصاطب مع كبس الخطوط مرتين مقارنة بالزر اعة على أرض مستوية.

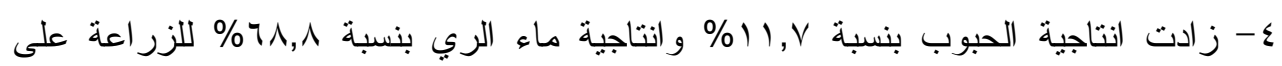

مصاطب مع كبس الخطوط مرتين مقارنة بالزر اعة على أرض مستوية.

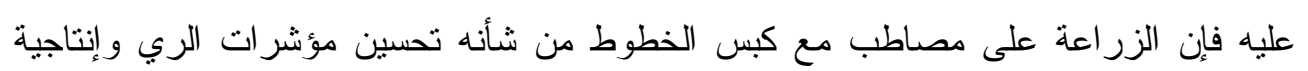
محصول القمح 